\title{
Freedom From; Freedom For - A Personal Reflection on the Life and Legacy of M. Cherif Bassiouni (1937-2017)
}

Mohamed Helal

Follow this and additional works at: https://via.library.depaul.edu/law-review

Part of the Law Commons

\section{Recommended Citation}

Mohamed Helal, Freedom From; Freedom For - A Personal Reflection on the Life and Legacy of M. Cherif Bassiouni (1937-2017), 68 DePaul L. Rev. (2019)

Available at: https://via.library.depaul.edu/law-review/vol68/iss4/2

This Article is brought to you for free and open access by the College of Law at Digital Commons@DePaul. It has been accepted for inclusion in DePaul Law Review by an authorized editor of Digital Commons@DePaul. For more information, please contact digitalservices@depaul.edu. 


\title{
FREEDOM FROM; FREEDOM FOR-A PERSONAL REFLECTION ON THE LIFE AND LEGACY OF M. CHERIF BASSIOUNI (1937-2017) ${ }^{\dagger}$
}

\author{
Mohamed Helal*
}

For a man who dedicated his life to upholding humanitarian values, to defending the defenseless, and to promoting accountability for the worst atrocities committed in war it is intriguing that Cherif Bassiouni was fond of men of war. His heroes were military men, such as General George S. Patton, and conquerors, such as Napoleon. In fact, there was many a time when he sat his wife, Elaine, and myself down to watch the film Patton. ${ }^{1}$ Visitors to his beloved lakeside house in Michigan were always amazed to find that he owned a collection of over 2,000 toy soldiers representing formations and units from Napoleon's Grande Armée. ${ }^{2}$ Nothing brought joy to Cherif as much as reenacting the great battles of the Napoleonic wars with these solider figurines.

Although their careers, lives, and legacies could not be more different, Napoleon Bonaparte, George S. Patton, and Cherif Bassiouni were similar in one respect. All three lived by and often repeated the

$\dagger$ Mahmoud Cherif Bassiouni passed away on the morning of September 25, 2017. He was a Distinguished Research Professor of Law Emeritus and President Emeritus of the International Human Rights Law Institute at DePaul University College of Law, Honorary President of the Siracusa Institute in Siracusa, Italy (formerly known as the International Institute of Higher Studies in Criminal Sciences (ISISC)), and Honorary President of L'Association Internationale de Droit Pénal. This Essay is based on an address delivered at the 28th DePaul Law Review Symposium titled The Intersection of International Criminal Law and Gender: Progress of the Past for the Goals of the Future, which was hosted in honor of Professor Emeritus M. Cherif Bassiouni and was held in Chicago, Illinois on March 23, 2018. It also draws on a tribute that was published by Opinio Juris on the day of Professor Bassiouni's passing. See Mohamed Helal, In Celebratus: M. Cherif Bassiouni (1937-2017), OpinioJuris (Sept. 26, 2017), http://opiniojuris.org/ 2017/09/26/in-celebratus-m-cherif-bassiouni-1937-2017/.

* Assistant Professor of Law, Moritz College of Law \& Affiliated Faculty, Mershon Center for International Security Studies, The Ohio State University.

1. Patton is an American film released in 1970 that depicts the life and battles of General George S. Patton of the U.S. Army during World War II. PAtтon (Twentieth Century Fox Apr. 2, 1970).

2. La Grande Armée was the French imperial army during the period 1805-1815 that was led by Napoleon Bonaparte during his campaigns throughout Europe. For a general history of Napoleon's army and its battles, see John Elting, Swords Around A Throne (1997). 
following saying, which was first coined by the French revolutionary Georges Danton: l'audace, encore de l'audace, toujours l'audace-audacity, more audacity, always audacity. ${ }^{3}$ Indeed, that was how Cherif approached his scholarship and his practice. He was an audacious academic who never shied away from pushing the intellectual envelope, and he was a daring practitioner who challenged political powers and spoke truth to power.

However, where Cherif differed from Napoleon and Patton was the motivation that fueled his audacity. When one reads the biographies of people like Napoleon and Patton, one is struck by the extent to which these men were motivated by the pursuit of glory. These were men who were singularly driven by a desire to glorify and immortalize their names, a pursuit in which they employed the weapons of war. Unlike Napoleon and Patton, however, Cherif was driven by a profoundly selfless and deeply humanist sense of mission, which he pursued with passion and audacity. His instruments on this mission were ideas, persuasion, theoretical innovation, and political creativity, which he presented to the academy in tens of books, hundreds of articles, and thousands of reports, statements, and lectures.

Cherif's mission in life, I believe, is captured in a single line in one of his earliest treatises. In 1969, only five years into his academic career, he published his fourth book, which was titled: Criminal Law and Its Processes: The Law of Public Order. ${ }^{4}$ On the dedication page of this book, in classic Cherif Bassiouni-style, Cherif quoted himself as saying: "True freedom is not freedom from but freedom for."5 I suspect that what Cherif was referring to here is similar to what British philosopher Isaiah Berlin described as the distinction between negative freedom and positive freedom. ${ }^{6}$ Negative freedom, or as Cherif put it, "freedom from," referred to the right of an individual to be free from interference. It was, in a sense, a right of individual self-determination; a right to be left alone. I think that, to Cherif, this was an unsatisfying and unfulfilling freedom. It was empty, lonely, and solitary. True freedom, he believed, was positive and purposeful-a "freedom for." A freedom dedicated to causes greater than one's own gain or individual benefit; a freedom exercised on behalf of others; a freedom that was fulfilled by upholding universal principles and by service to one's community and one's fellow human beings.

3. Paul Johnson, Napoleon 21 (2002).

4. M. Cherif Bassiouni, Criminal Law and Its Processes: The Law of Public Order (1969).

5. $I d$.

6. See Ian Hunt, Freedom and Its Conditions, 69 Australian J. Phil. 288, 288 (1991). 
This sense of mission and this understanding of the nature of freedom accorded with Cherif's religious views. Cherif was a Muslim. $\mathrm{He}$ was not, however, a strictly observant Muslim. But he was a deeply spiritual man. Cherif believed that freedom was a divine gift-a grant from God-and that when our souls depart this world, God will judge us on how and for what purposes we used that freedom. Cherif believed that the most worthy use of our God-given freedom was to act as God's agents on earth by serving, protecting, and caring for the other creatures of God. I think he felt a deep sense of responsibility towards God to dedicate his own individual freedom to the service of others, and through that, I think he believed he would be serving God. Indeed, Cherif once wrote that:

[W] are all creatures of the Almighty and ... we will all one day be accountable to Him. In the meantime, while on earth, we must do as much good as we can, and as little evil as we can; and we must act with dignity, honor, and honesty. We must use our good fortune to commit to something bigger and better than the pursuit of personal interests and pleasures. ${ }^{7}$

Cherif also often cited this narration, which is attributed to the Prophet Mohammed: "If you see a wrong you must right it; with your hand if you can, or, with your words, or, with your stare, or in your heart, and that is the weakest of faith." International criminal law was Cherif's instrument to right the many wrongs he witnessed throughout the world. Developing the doctrinal content of this field of international law and proposing accountability mechanisms that would both hold perpetrators of international crimes accountable and vindicate the rights of victims was a mission, perhaps even a religious obligation; to right wrongs, uphold justice, and promote universal humanistic values. ${ }^{9}$

This religious and moral outlook explains Cherif's affection for DePaul University, where he taught from 1964 until he retired in 2012. Cherif was not a Catholic, but he was schooled in an elite

7. M. Cherif Bassiouni, Bearing Witness, in Pioneers of Genocide Studies 315, 328 (Samuel Totten \& Stephen Leonard Jacobs eds., 2002).

8. For an example of Cherif's fondness for this quotation, see M. Cherif Bassiouni, Searching for Peace and Achieving Justice: The Need for Accountability, 59 L. \& ConTEMP. Probs. 9, 9 (1996) [hereinafter Bassiouni, Searching for Peace and Achieving Justice].

9. As Cherif once said: "International criminal law is a reflection of certain humanistic values, which I think are here to remain. So, these values are going to have to find a way of expressing themselves." Anja Matwijkiw \& Bronik Matwijkiw, M. Cherif Bassiouni (1937-2017), 17 Global Community Y.B. InT'L L. \& Juris. 15, 23 (2018) (quoting M. Cherif Bassiouni, Distinguished Speaker at the Advanced Course on International Criminal Law hosted by the Grotius Centre for International Legal Studies and the Hague Academy of International Law: The Future of International Criminal Justice (Sept. 2015), https://www.youtube.com/watch?v=qA2Ou 4E_Wko). 
Francophone Jesuit boarding school in Cairo, where his temperament, disposition, and moral compass were shaped by Jesuit principles and values. Just as St. Vincent DePaul said: "Go to the poor: you will find God," much of Cherif's scholarship and advocacy was driven by the belief that by defending the meek, vindicating the victimized, and resisting oppression he would come closer to God. These moral commitments and spiritual beliefs were the motivating force underlying Cherif's scholarship. They drove him to produce a staggering record of 35 authored books, 44 edited volumes, and over 270 law review articles.

But Cherif also put his ideas and moral commitments into action through his practice. Cherif Bassiouni was a scholar-practitioner. $\mathrm{He}$ led investigative commissions in Bahrain, Libya, and the famed Yugoslavia Commission, in addition to being appointed as the Independent Expert on Human Rights in Afghanistan by the United Nations. ${ }^{10}$ On each of these commissions and appointments, Cherif not only executed his mandate with professionalism and ingenuity, but he also felt that he was on a mission-a humanitarian mission.

It was my privilege to personally witness Cherif in action while serving as the Legal Officer of the Bahrain Independent Commission of Inquiry, which Cherif chaired. During a visit to a women's detention facility, a team from the Commission led by Cherif met two high-profile detainees who were among the leaders of the anti-government protests that broke out in Bahrain in February of 2011. These detainees recounted to us the inhumane and degrading treatment to which they were subjected during interrogation and during their imprisonment. As we left the detention facility, Cherif appeared shaken. $\mathrm{He}$ told us that he was determined to secure the release of these women and that he would raise the matter with the King of Bahrain. As a disciplined positivist lawyer, I looked at Cherif and said: "That's not our mandate. Our job is to investigate allegations of human rights abuse and to faithfully report our findings. We're impartial investigators not activists." He looked at me and said: "Yes, we're investigators, but we're also here to do good." He then went on to recount an incident that happened during his service as the UN Independent Expert for Human Rights in Afghanistan.

10. See Human Rights Council on Its Seventeenth Session, Report of the International Commission of Inquiry to Investigate All Alleged Violations of International Human Rights Law in Libyan Arab Jamahiriya, U.N. Doc. A/HRC/17/44 (Extract), at 2 (June 1, 2011) (listing Cherif "as the Chairperson of the commission"); Press Release, Acting High Commissioner for Human Rights Welcomes Appointment of Independent Expert on Afghanistan, U.N. Press Release AFG/253-HR/4730 (Apr. 7, 2004). 
The incident Cherif then recounted had occurred during one of his tours of Afghanistan, where he found a detention facility in which 852 Afghan men were being held in despicable conditions. When he investigated the matter, Cherif discovered that these men had been held incommunicado $^{11}$ for over two years because U.S. Attorney General John Ashcroft wanted them to remain detained until they were interrogated. That night, after witnessing the agony and misery of these detainees who were neither charged nor indicted of any crimes, Cherif knelt to the ground and prayed to God. He said: "I truly want you to make me an instrument of these people's freedom. I do not want reward or recognition-I just want the satisfaction of getting these people out." The next morning, Cherif launched a campaign to set these men free. He met U.S. Ambassador Zalmay Khalilzad and virtually everyone in the Afghan government to secure the release of these men, including the Chief Justice, the Attorney General, the Minister of Interior, and President Hamid Karzai. In each of these meetings, Cherif gave the Afghan Government an ultimatum: He threatened to announce and widely publicize this unjust mass incarceration in his report to the UN Secretary General, unless these men were released. Sure enough, a few days after he returned to his office at the DePaul University College of Law, his representative in Kabul called to inform him that the 852 men had been released and returned to their families.

After recounting this story to our team from the Commission, Cherif-unable to hold back his tears-got off his chair and knelt to pray to God in thanks. Naturally, having heard this moving story, I relented (not that it was up to me to decide whether Cherif discussed the matter of the women detainees with the King of Bahrain anyway). Cherif discussed the matter with Bahrain's King Hamad, and sure enough, weeks later the detained women were released.

Cherif's family history and upbringing also contributed to instilling in him this sense of mission. Cherif was a child of fortune who hailed from Egypt's landed aristocracy. His mother was a Lady-in-Waiting for Egypt's Queen and served as her bridesmaid at her wedding to King Farouk I. His maternal grandmother was a Habsburg princess from Austria and her husband, Cherif's maternal grandfather, was the Legal Counsel of Egypt's King Fouad I. Cherif's father was a distinguished diplomat and an Ambassador who was educated in Oxford,

11. As a type of indefinite detention, incommunicado detention refers to the deprivation of individual liberty without providing proper legal justification, without timely legal proceedings, and without access to legal counsel or family. See Alfred de Zayas, Human Rights and Indefinite Detention, 87 InT'L Rev. Red Cross 15, 17 (2005). 
and Cherif's paternal grandfather was the first President of the Egyptian Senate, which was established in 1923 after Egypt gained independence from Britain in 1922.

So, in short, Cherif Bassiouni was as blue-blooded as they get. But he was never satisfied or satiated by the liberties and freedoms guaranteed by his family's connections, political power, and financial wherewithal. The privileged, almost regal, childhood that Cherif enjoyed inculcated him with a deep desire to serve. It was almost as if he needed to justify to himself the many freedoms and liberties that his familial background afforded him. Signs of this desire to serve were apparent from his early childhood. One afternoon, in 1943, his father received an unfamiliar guest in their home. Although he was not in the room, an ever-curious and ever-mischievous Cherif listened in on the conversation. He saw this man roll up his sleeve to reveal a number that had been tattooed on his forearm. Later, Cherif's mother explained to him that there was a "bad man" in Europe who was taking certain people, tattooing numbers on their arms, and killing them. Who were these people, and why was the "bad man" killing them, asked Cherif. Unable to reveal the full extent of the terrible truth to her son and unable to contain her emotions, Cherif's mother simply told him that these people were Jewish like "Mr. so-and-so" and "Ms. so-and-so," who were Jewish friends of the Bassiouni family. And she added that the "bad man" didn't like these people only because they were Jewish. This experience left a lasting impression on Cherif. It introduced this seven-year-old boy to the existence of evil and ingrained in him a reflexive desire to defend the voiceless and the powerless and to resist those who commit such atrocities.

Cherif's work and life were also informed by a belief in the unity of our human family. Throughout his writings he invoked the concept of the civitas gentium maxima, which was originally articulated by the German philosopher Christian Wolff. ${ }^{12}$ Cherif, like Wolff, believed that humanity constituted a civitas maxima-a universal community of humankind that shared a set of immutable values. ${ }^{13}$ Cherif was not oblivious to the political, social, and religious diversity of humanity, but he believed that despite our different colors, cultures, and creeds, humanity shares certain universal moral precepts. For Cherif, the civ-

12. M. Cherif Bassiouni \& Edward M. Wise, Aut Dedere, Aut Judicare: The Duty to Extradite or Prosecute in International Law 29-30 (1995) ("Various terms have been used to refer to this hypothetical international community. That popularized by Christian Wolff in the eighteenth century speaks of a civitas maxima, a supreme state or body politic.").

13. 1 M. Cherif Bassiouni, Introduction to International Criminal Law 39 (2d ed. 2012). 
itas maxima was not a theoretical construct or a conceptual assumption about the state of nature-it was an empirical reality. As he wrote in a hugely influential tome that he coauthored with Edward Wise on the principle of aut dedere aut judicare:

The idea of the world as a single community, a "community of mankind," . . . primarily expresses a sense of human solidarity of common humanity. It postulates certain universal objects and moral imperatives that are believed, in principle, to limit the action of states and impel them to cooperate for the common good of a community of which everyone in the world was ultimately a member.... [I]t is belief in the ultimate reality of this civitas maxima that underlies assertions about a common interest in repressing crime wherever it occurs (and also assertions about the existence of a genuine body of international criminal law). ${ }^{14}$

This claim of the existence of a civitas maxima based on universal values has led some scholars to label Cherif as a natural lawyer-a 20th century intellectual descendant of a long and distinguished line of theologians, philosophers, writers, and thinkers extending from: St. Augustine and St. Thomas Aquinas in antiquity, to Grotius and Pufendorf in the Middle Ages, to modern-day scholars, such as Finnis, Fuller, and Dworkin. ${ }^{15}$ I, however, disagree with that characterization of Cherif's work and his intellectual disposition. I say that, not because I am a positivist with an allegiance to the work and thought of jurists like Vattel, Hart, and Kelsen, but because I feel that Cherif Bassiouni was too pragmatic and too versatile of a scholar to be fully committed to the stringent assumptions of natural law. He was not a dreamy idealist nor was he under the illusion that the law is, in the words of Justice Holmes, "a brooding omnipresence in the sky." 16 Cherif was too rooted in reality to accept the claim that law ought to be validated by reference to some immutable moral principles. He was too well trained as a law student in France and Switzerland by classical positivists to accept the proposition that a properly enacted rule of law could be ignored or repealed because it violated a putative moral precept. He also understood that in an anarchic world system, which lacked a central legislating authority, it would be untenable to argue

14. BAssiouni \& Wise, supra note 12 , at 28-30.

15. Anja Matwijkiw \& Bronik Matwijkiw, A Modern Perspective on International Criminal Law: Accountability as a Meta-Right, in The Theory And Practice of International Criminal Law: Essays in Honor of M. Cherif Bassiouni 19, 69 (Leila Nadya Sadat \& Michael P. Scharf eds., 2008) (arguing that "Bassiouni opted for natural law theory. . . . Bassiouni's parameters ascribed primacy to morality so as to make it possible to argue that bad law is not law in the strict and proper sense ... . For Bassiouni, enforcement is important, even a parameter, but only on condition that the law itself is just.").

16. S. Pac. Co. v. Jensen, 244 U.S. 205, 222 (1917) (Holmes, J., dissenting) ("The common law is not a brooding omnipresence in the sky ...."). 
that moral principles could override rules of law generated by the consent of sovereign states.

Therefore, instead of a natural lawyer, I would categorize Cherif as a pragmatic but principled positivist. He was a positivist because he always sought to distinguish between lex lata and de lege ferenda. He carefully differentiated between the established law and his own proposals for legislative reform, and his descriptions of the state of the law were always rigorously supported by ample state practice. But Cherif was a principled positivist. He was deeply unsatisfied with the state of international law, and he dedicated his life to bridging the gap between his humanitarian moral commitments and the harsh statecentric reality of international law. Unlike natural lawyers in bridging this gap, Cherif adopted a methodology that was strategic, pragmatic, and that took into consideration the political context in which international criminal law operated.

One example of Cherif's principled positivism is his scholarship on universal jurisdiction. Universal jurisdiction allows a state to prosecute an individual who commits certain international crimes, even in the absence of any nexus between the perpetrator and the prosecuting state. ${ }^{17}$ Understandably, many international criminal lawyers actively advocate for universal jurisdiction. Many scholars have written in support of universal jurisdiction and have cited precedents, such as the Eichmann Case in Israel and the Pinochet Case in Spain and Britain, as evidence of the establishment or at least the emergence of a principle of universal jurisdiction. ${ }^{18}$ Cherif, however, was more cautious and more measured in his readings of these cases. Cherif carefully examined the indictments and judgments in these cases and interpreted them not as examples of universal jurisdiction, but as exercises of jurisdiction on alternative, well-established, and much less controversial grounds-such as the identity of the victims in the Eichmann Case, and the Convention Against Torture, in the Pinochet Case. ${ }^{19}$

17. See generally M. Cherif Bassiouni, Universal Jurisdiction for International Crimes: Historical Perspectives and Contemporary Practice, 42 VA. J. INT'L L. 81 (2001).

18. See generally Leila Nadya Sadat, Redefining Universal Jurisdiction, 35 NEw ENG. L. REv. 241 (2001). For in-depth discussions of the Israeli court opinions in the Eichmann Case and the British court opinion in the Pinochet Case, and the relevancy of these opinions to universal jurisdiction, see, respectively, Covey Oliver, Judicial Decisions: Jurisdiction of Israel to try Eichmann-International Law in Relationship to the Israeli Nazi Collaborators (Punishment) Law, 56 Aм. J. INT'L L. 805 (1962); and Regina v. Bartle and the Commissioner of Police for the Metropolis and others Ex Parte Pinochet, 38 I.L.M. 581 (H.L. 1999) (UK), https://www.asser.nl/upload/ documents/20120516T100228-Pinochet_House_of_Lords_Opinion_25-11-1998.pdf.

19. See Diane F. Orentlicher, Universal Jurisdiction: A Pragmatic Strategy in Pursuit of a Moralist's Vision, in The Theory and Practice of International Criminal Law, supra note 15, at 127,134 . Universal jurisdiction is a unique form of jurisdiction because, generally, interna- 
Cherif was uncomfortable with legal reasoning and scholarly argumentation that was unmoored from reality or that had limited foundation in state practice. And so, he promoted universal jurisdiction by basing it in accepted principles and established law. He argued that jus cogens prohibitions on international crimes, such as the prohibitions on genocide, crimes against humanity, war crimes, and torture, generated an ancillary duty to either prosecute or extradite perpetrators of these crimes. As he wrote in a 1997 law review article:

$[\mathrm{R}]$ ecognizing certain international crimes as jus cogens carries with it the duty to prosecute or extradite, the non-applicability of statutes of limitation for such crimes, and universality of jurisdiction over such crimes irrespective of where they were committed, by whom (including Heads of State), against what category of victims, and irrespective of the context of their occurrence (peace or war). Above all, the characterization of certain crimes as jus cogens places upon states the obligatio erga omnes not to grant impunity to the violators of such crimes. ${ }^{20}$

Through his scholarship and advocacy, Cherif sought to extrapolate a principle of universal jurisdiction from established legal doctrine. $\mathrm{He}$ endeavored to extend and develop rules, such as the doctrine of jus cogens, which were accepted as valid by states to provide a firm basis for progressive legal reform. Moreover, Cherif always used his encyclopedic knowledge of comparative criminal law and procedure to design smart and practical legislative reforms that would address the concerns of states that were skeptical of the possibility of the misuse or politicization of universal jurisdiction. That was Cherif's scholarly modus operandi. His methodology was pragmatic, positivistic, and rigorous. But his humanitarian ethics and moral commitments were his lodestar-they served as a moral compass that determined the path of his scholarship.

His ethics also shaped his practice. He was meticulous, creative, and audacious, but he was not cavalier or impudent. He was fiercely protective of his professionalism and political independence, and he never succumbed to pressure or persuasion from government officials as he pursued justice and promoted accountability. For instance, Cherif investigated the crimes committed in the armed conflict in the

tional law requires some nexus or connection between a prosecuting state and the defendant, such as the location of the crime or the citizenship of either the defendant or the victim. See Bartram S. Brown, The Evolving Concept of Universal Jurisdiction, 35 NEw ENG. L. REv. 383, 383 (2001) ("Traditionally, international law requires some link of territory or nationality to a crime as the basis for a state's exercise of criminal jurisdiction. Universal jurisdiction is a special exception to this rule ....").

20. M. Cherif Bassiouni, International Crimes: Jus Cogens and Obligatio Erga Omnes, 59 L. \& Contemp. Probs. 63, 65-66 (1997). 
former Yugoslavia. Those in charge of the political negotiations, who were seeking a settlement to the conflict at all costs, were concerned that Cherif and the Yugoslavia Commission's investigations, and the evidence uncovered and documented, might derail the political process. Those negotiators repeatedly coaxed and cajoled Cherif to alter his findings or to blunt the severity and clarity of his criticism. They intimated to him that it was politically desirable to find a moral equivalence between the belligerents. They wanted him to find that the warring parties - the Serbs, the Croats, and the Bosnian Muslimswere equally guilty and equally victimized. For instance, in May of 1993, Cherif had an impromptu meeting with Lord David Owen, who was the European Union Co-Chairman of the International Conference on the Former Yugoslavia, in the cafeteria of the Geneva headquarters of the United Nations. After exchanging pleasantries, Owen asked Cherif whether it was true that his team had uncovered a mass grave of about seventy Bosnian Muslims who had been murdered by Serbs. When Cherif said that was true, Owen asked whether it was true that his team had also found another mass grave of seventy Serbs murdered by Bosnian Muslims and another grave of seventy Croats also murdered by Bosnian Muslims. Cherif appeared startled and said that no such graves had been found, but Owen insisted that these graves existed and encouraged Cherif to report these fictitious mass graves. It was then that Cherif realized he was being asked to alter the historical record to generate an equality of blameworthiness between the belligerents. Cherif would have none of it. ${ }^{21} \mathrm{He}$ remained steadfast in his pursuit of the truth. He rejected the age-old dichotomy between peace and justice; he contested the claim that accountability had to be compromised in order to realize a political settlement; he firmly believed that a durable, sustainable, and lasting peace could only be achieved on the foundations of justice. Cherif was unswerving in his belief in the following Talmudic injunction that he quoted in many of his articles, books, and speeches: "The world rests on three pillars: on truth, on justice[,] and on peace. . . If justice is realized, truth is vindicated and peace results." 22

Cherif often paid a price for his steadfastness and his commitment to his values. For instance, after the Security Council established the

21. For this incident and a full account of Cherif's work in the former Yugoslavia, see generally M. Cherif Bassiouni, Investigating War Crimes in the Former Yugoslavia War 1992-1994 (2017) [hereinafter Bassiouni, Investigating War Crimes].

22. For an example of Cherif's fondness for this quotation, see Bassiouni, Searching for Peace and Achieving Justice, supra note 8, at 9 (alteration in original), in which Cherif opens his writing with these words. 
International Criminal Tribunal for the former Yugoslavia, Secretary General Boutros Boutros-Ghali nominated him to serve as the first prosecutor of the Tribunal. Given that he was not exactly responsive to political pressure, some Permanent Members of the Security Council, especially Britain and France, expressed misgivings about appointing him to that position. Instead, Madeline Albright, who was then serving as the U.S. Permanent Representative to the United Nations, suggested that if Cherif were to withdraw his nomination to the position of prosecutor, he would be guaranteed a judgeship on the Tribunal. Of course, having already investigated many of the crimes that would be brought before the Tribunal, Cherif knew he would have had to recuse himself from these cases. This meant that he would have just sat at home in a luxurious house in The Hague while being paid the annual tax-free salary of an Under-Secretary-General of the United Nations. Cherif, of course, rejected the offer that would have tempted many, many others. ${ }^{23}$ That was who Cherif was. He dedicated his life to the righting of the many wrongs that afflict our world. He did this through his writing, his teaching, his advocacy, his volunteerism, and his involvement with the United Nations-all of which were motivated by a commitment to confront tyranny and to promote human dignity. He did this with professionalism, intellectual ingenuity, and integrity.

In addition to his professional pursuits, Cherif, or "MCB" as his family and friends called him, was a multifaceted man of many talents and multiple layers of identity. Cherif was an immensely proud Egyptian. There is no story that he enjoyed telling as much as that of his fighting in the 1956 Suez War. But Cherif was also a citizen of the world and a proud naturalized American. He unwaveringly believed in those universal, self-evident truths that are the foundation of the ideals that make America great. He was an unrelenting advocate of the unalienable right of every human being to pursue a life of liberty, dignity, and happiness.

Cherif was a force of nature. He wrote his latest book on the former Yugoslavia while battling multiple myeloma. Cherif was a perfectionist. As Kelly McCracken-Pembleton, Giovanni Pasqua, Assia Buonocore, Filipo Musca, Stefania Lentinello, Neil Townsend, Jessica DeWalt, Daniel Swift, Deirdre McGrory, Douglass Hansen, Molly Bench, Kandy Christensen, Meredith Barges, Jennifer Gerard, Kari Kammel, Mohamed Abdel Aziz, and all those who worked with him know, Cherif was a tough taskmaster. He was an obsessive micro-

23. Bassiouni, Investigating War Crimes, supra note 21, at 109-10. 
manager who paid close attention to every substantive and procedural detail of his work. But he also cared deeply about our lives. To many of us, especially Khaled Ahmed, Yaser Tabbara, Ahmed Rehab, Kelly McCracken-Pembleton, and myself, he was our adoptive father. $\mathrm{He}$ advised us on our education, counseled us on our careers, consoled us during life's trials and tribulations, and mediated arguments with our significant others. Cherif was omnipresent in the lives of all those around him, and for many of us, including myself, he was our anchor. Cherif was also a consummate educator who cared deeply about his students. He always sought to nurture their ability to apply the law rigorously and to live up to the highest ideals of justice to which the legal profession aspires.

Cherif was a patron of the arts, a connoisseur of fine wines, and an amateur singer (although I wouldn't count this as one of his outstanding talents!). He was an aristocrat who walked with kings, but never lost the common touch. ${ }^{24}$ His charm, his charisma, and his sense of humor were enrapturing. His soul was generous and his heart compassionate; he was an unmatched orator, an inspiring teacher, a gifted wordsmith, a spectacular storyteller, and a supreme scholar of encyclopedic knowledge. Cherif was a warrior for justice. He confronted the worst in man with the best in man, he fought might with right, and stood for virtue in the face of evil.

In closing, it is fitting to quote a prayer that Cherif used to conclude the last book that he published, which feels like a message to us all from a departing giant:

Now, go forth into the world in peace. Be of good courage. Hold fast to that which is good. Render to no one evil for evil. Strengthen the faint-hearted. Support the weak. Help the afflicted. Honor all people. Love and serve the Lord rejoicing in the power of the Holy Spirit. ${ }^{25}$

-Farewell, MCB! Gone, but never forgotten. May you rest in peace.

24. Rudyard Kipling, If, in Rudyard Kipling's Verse: Inclusive Edition 1885-1918 645-46 (1922) ("Or walk with Kings-nor lose the common touch . . . !").

25. Bassiouni, Investigating War CRimes, supra note 21 , at 452 n.43. 